\title{
Intraoperative Monitoring of Parathormone in the Surgical Treatment of Renal Hyperparathyroidism
}

\author{
Costin Pasnicu, Petru Radu, Mircea Brătucu, Iustinian Bengulescu, Vlad Paic, Mihai Zurzu, Florian Popa, \\ Victor Strâmbu
}

Department of Surgery, Carol Davila Clinical Hospital of Nephrology, Bucharest, Romania

Corresponding author:

Petru Adrian Radu, MD

Department of Surgery

Carol Davila Clinical Hospital of

Nephrology, Bucharest, Romania

E-mail: drradupetru@yahoo.com

Abbreviations:

HPT - Hyperparathyroidism;

sHPT - Secondary Hyperparathyroidism;

PTH - Parathyroid Hormone;

PTH - Parathormone;

IPTH - Intraoperative Parathyroid Hormone;

TPTX - total parathyroidectomy

CKD- Chronic Kidney Disease

\section{Rezumat}

Monitorizarea intraoperatorie a parathormonului în tratamentul chirurgical al hiperparatiroidismului secundar de cauză renală

Introducere: Monitorizarea intraoperatorie a hormonului paratiroidian poate confirma excizia în totalitate a țesutului paratiroidian hiperfuncțional, întrucat timpul de înjumatațire plasmatică al PTH-ului este de aproximativ 5 min.

Material şi Metodă: Scopul acestui studiu a fost de a analiza valorile parathomonului (PTH) şi impactul intraoperator la pacienții cu hiperparatiroidism secundar de cauză renală (sHPT). Au fost incluşi în studiu o serie de 86 de pacienți, care au fost internați în clinica noastră în perioada februarie 2015-decembrie 2018. Toți pacienții au fost supuşi unei intervenții chirurgicale, $\mathrm{cu}$ monitorizarea PTH-ului. PTH-ul a fost determinat preoperator, intraoperator la 15 minute dupa efectuarea paratiroidectomie şi postoperator.

Rezultate: Din totalul de 86 de pacienți 6 pacienți prezentau transplant renal nefuncțional. 81 de pacienți au fost operați perprimam iar 5 pacienți au fost operați pentru recurența bolii. S-au practicat 77 de paratiroidectomii totale si 4 paratiroidectomii subtotale. Un pacient a prezentat 5 glande paratiroide. Au fost 4 pacienți cu recurență hiperparatiroidiană la care s-a practicat excizia tesutului hiperplazic. Probele de sânge au fost recoltate intraoperator prin punctia venei jugulare. Valoarea PTH-ului a fost determinate prin testul Elecsys PTH STAT ${ }^{\circledR}$. Valoarea medie a PTH-ului preoperator a fost de $1658 \mathrm{pg} / \mathrm{mL}$ şi care a scăzut la 46,5 $\mathrm{pg} / \mathrm{mL}$ la sfârşitul operației. Ulterior nivelul PTH-ului recoltat la 3-6 luni a crescut uşor până la 59,8 pg/mL. 80 (93\%) din pacienți au 
prezentat valori crescute ale calciului preoperator. Hiperparatiroidismul recurent s-a întalnit la 1 pacient din cei 4 la care s-a practicat paratiroidectomie subtotală.

Concluzii: Valoarea iPTH este influențată de manipularea intraoperatorie a glandelor paratiroide, variabilitatea individuală a timpului de înjumatățire a PTH-ului şi de starea fiziologică a pacientului. Scăderea PTH-ului măsurat intraoperator la $15 \mathrm{~min}$ de la recoltare cu cel puțin $90 \%$ din valoarea preoperatorie indica succesul unei paratiroidectomii totale, cu normalizarea calciului şi a PTH-ului postoperator.

Cuvinte cheie: hiperparatiroidism secundar, boală cronică de rinichi, paratiroidectomie, parathormon, dozare intraoperatorie PTH

\section{Abstract}

Introduction:Intraoperative monitoring of parathyroid hormone can confirm the complete excision of hyperfunctional parathyroid tissue, as the plasma half-life of PTH is approximately 5 minutes.

Material and Method:The purpose of this study was to analyse the values of parathormon (PTH) and the intraoperative impact in patients with secondary hyperparathyroidism of renal cause (sHPT). A series of 86 patients who were hospitalised in our clinic between February 2015 to December 2018, were included in the study rom. All patients underwent surgery with PTH monitoring. PTH was determined preoperatively, intraoperatively 15 minutes after parathyroidectomy and postoperatively.

Results: Out of a total of 86 patients, 6 patients had non-functional renal transplant. 81 patients were operated on per primam and 5 patients were operated for disease recurrence. There were 77 total parathyroidectomies and 4 subtotal parathyroidectomies. One patient had 5 parathyroid glands. There were 4 patients with recurrent hyper-plastic tissue excision. Blood samples were collected intraoperatively through the puncture of the jugular vein. The PTH value was determined by the Elecsys PTH STAT ${ }^{\circledR}$ test. The mean value of preoperative PTH was $1658 \mathrm{pg} / \mathrm{mL}$ and decreased to $46.5 \mathrm{pg} / \mathrm{mL}$ at the end of the operation. Subsequently, the level of PTH harvested at 3-6 months increased slightly to $59.8 \mathrm{pg} / \mathrm{mL}$. 80 (93\%) of patients had elevated preoperative calcium values. Recurrent hyperparathyroidism was found in 1 of the 4 patients who underwent subtotal parathyroidectomy.

Conclusions: IPTH value is influenced by the intraoperative manipulation of the parathyroid glands, the individual variability of PTH half-life and the physiological state of the patient. The decrease of PTH measured intraoperatively at 15 minutes after harvest with at least $90 \%$ of the preoperative value indicates the success of a total parathyroidectomy, with normalisation of calcium and PTH.

Key words: secondary hyperparathyroidism, chronic kidney disease, parathyroidectomy, parathyroid hormone, intraoperative PTH

\section{Introduction}

Renal secondary hyperparathyroidism is a controversial topic of patients with chronic kidney disease (CKD) undergoing hemodialysis, defined as an increase in serum parathyroid hormone (PTH). The surgical treatment applied to patients with sHPT results in a reduction of the symptoms and a significant improvement of the quality of life. $(1,2)$.

The first publication describing the use of intraoperative PTH was in 1988 (3). In most studies, the success of surgical treatment in 
these patients is over $95 \%(4,5,6)$. Routine use of intraoperative PTH is a necessity in the current surgical treatment of hyperparathyroidism $(7,8)$.

Intraoperative monitoring of parathormone (iPTH) has significantly changed the approach of surgical treatment of hyperparathyroidism, from the traditional technique with exposing the thyroid lobe and highlighting the 4 glands to minimally invasive parathyroidectomy. (9)

The parathormone is composed of a polypeptide of 84 amino acids, is secreted by the parathyroid glands and regulates the level of calcium ions in the blood stream. PTH is largely eliminated in the liver, but also in the kidney and bone. The N-terminal fragment of PTH confers bioactivity with a short half-life of up to 5 minutes (10). The C-terminal fragment has a half-life of several hours and is eliminated by glomerular filtration, dependent on renal function $(11,12)$.

Studies on the reliability of a rapid PTH evaluation test have been reported in the surgical treatment of primary and secondary hyperparathyroidism, but also in patients with over-numbered parathyroid glands since 1991 (13).

Starting from this publication, in many studies, aspects regarding the half-life and reliability of the various rapid tests for PTH determination have been widely discussed.

\section{Material and Method}

In this study we analysed the values of PTH and the intraoperative impact in patients with secondary hyperparathyroidism of renal cause (sHPT). A series of 86 patients (52 men, 34 women), who were hospitalised in our clinic between January 2015 and December 2018, were included in the study. All patients underwent intraoperative PTH measurement. 81 patients were operated on for the first time and 5 patients were operated on a second time for disease recurrence. Of the 81 surgeries, 77 total parathyroidectomies and 4 subtotal parathyroidectomies were performed. The 5 patients hospitalized for hyperparathyroid recurrence underwent hyperplasia of the remaining parathyroid tissue. There was a patient who had over-parathyroid parathyroid, the 5th gland having intratymic localization.

The average age of the patients was 61 years with a minimum age of 18 years and a maximum of 74 years.

Of the 86 patients, 5 patients were admitted for hyperparathyroid recurrence, and a single hyperplastic parathyroid gland was identified.

Cervical thymectomy was not performed routinely but only in the patient who presented with a parathyroid gland with ectopic, intratymic localization. The parathyroid glands were subsequently confirmed by anatomopathological examination.

$80(93 \%)$ of patients had elevated preoperative calcium values.

Intraoperative PTH was determined 15 minutes after total parathyroidectomy by Elecsys PTH STAT ${ }^{\circledR}$ test. This third generation test uses a sandwich principle that targets both the C-Terminal and the N-Terminal fragment through a monoclonal antibody. The assay has a $99.6 \%$ sensitivity and $93.7 \%$ specificity when respecting the guidelines.

\section{Results}

A series of 86 patients (52 men, 34 women) who were hospitalised in our clinic between January 2015 and December 2018 were included in the study and underwent surgery with intraoperative measurement of PTH.

The average age of the patients was 61 years with a minimum age of 18 years and a maximum of 74 years.

The mean levels of preoperative PTH were $1658 \mathrm{pg} / \mathrm{ml}$ with a minimum of 784.21 and a maximum of $2751.36 \mathrm{pg} / \mathrm{ml}$. The average duration of dialysis was 4.6 years with a minimum of 2 years and a maximum of 12.5 years. Serum creatinine had a mean value of $6.8 \mathrm{mg} / \mathrm{dl}$ with a minimum of $5.4 \mathrm{mg} / \mathrm{dl}$ and a maximum of $10.8 \mathrm{mg} / \mathrm{dl}$. The value of transferrin in patients had an average value of $154 \mathrm{mg} / \mathrm{dl}$ with a minimum of $18 \mathrm{mg} / \mathrm{dl}$ and a maximum of $575 \mathrm{mg} / \mathrm{dl}$. The mean phosphatase value in patients had an average 
Table 1. Demographic, clinical and laboratory characteristics of the patients $(n=86)$

\begin{tabular}{ll}
\hline Parameter & Data \\
\hline Women / Men & $34 / 52$ \\
\hline Age $(\mathrm{y})$ & $61(18-74)$ \\
\hline Preoperative PTH $(\mathrm{pg} / \mathrm{ml})$ & $1658(784.21-2751.36)$ \\
\hline Average duration of dialysis $(\mathrm{y})$ & $4.6(2-12,5)$ \\
\hline Creatinine $(\mathrm{mg} / \mathrm{dl})$ & $6.8(5.4-10,8)$ \\
\hline Transferin $\mathrm{mg} / \mathrm{dl}$ & $154(18-575)$ \\
\hline Alkaline phosphatase $(\mathrm{U} / \mathrm{l})$ & $188.5(28.4-1212)$ \\
\hline Serum urea $(\mathrm{mg} / \mathrm{dl})$ & $158(130-212)$ \\
\hline Total Calcium $(\mathrm{mg} / \mathrm{dl})$ & $9.4(8.8-10.2)$ \\
\hline Phosphorus $(\mathrm{mg} / \mathrm{dl})$ & $12.7(7.7-28.4)$ \\
\hline
\end{tabular}

value of $188.5 \mathrm{u} / \mathrm{l}$ with a minimum of $28.4 \mathrm{u} / \mathrm{l}$ and a maximum of $1212 \mathrm{u} / \mathrm{l}$. Serum urea has an average value of $158 \mathrm{mg} / \mathrm{dl}$ with a minimum of $130 \mathrm{mg} / \mathrm{dl}$ and a maximum of 212 $\mathrm{mg} / \mathrm{dl}$. The total calcium had an average value of $9.4 \mathrm{mg} / \mathrm{dl}$ with a minimum of $8.8 \mathrm{mg} / \mathrm{dl}$ and a maximum of $10.2 \mathrm{mg} / \mathrm{dl}$. (Table 1 ).

All patients underwent surgery. 81 patients were operated on for the first time by sHPS, and 5 were operated for the second time for disease recurrence. Of the 81 patients, 77 underwent total parathyroidectomy and 4 underwent subtotal parathyroidectomy. There was a case in which 5 parathyroid glands were confirmed anatomopathologically. The supranumerary parathyroid had an ectopic localization at the mediastinum (Table 2).

5 patients of the 86 patients, were hospitalised for hyperparathyroid recurrence, and a single hyper-plastic parathyroid gland was identified.

After a follow-up period of up to 6 months, 82 patients (95\%) out of 86 had serum calcium and PTH within normal limits.

Recurrent hyperparathyroidism was found in 1 of the 4 patients who underwent subtotal parathyroidectomy.

The mean levels of preoperative PTH were $1658 \mathrm{pg} / \mathrm{ml}$ (784.21-2751.36 pg/ml). At 15 minutes after total parathyroidectomy, the PTH level decreased to an average of $46.5 \mathrm{pg} / \mathrm{ml}$. After a maximum of 6 months it increased slightly to $59.8 \mathrm{pg} / \mathrm{ml}$ (Fig. I).

The PTH had an average decrease of $87 \%$ (41\% -98\%). 84 patients (98\%) had a decrease
Table 2. Surgical procedures in 86 patients

\begin{tabular}{ll}
\hline Parameter & Data \\
\hline First operation for sHPT (\%) & $81(94 \%)$ \\
\hline Total pharathyroidectomy(\%) & $77(89.5 \%)$ \\
\hline Subtotal pharathyroidectomy(\%) & $4(4.6 \%)$ \\
\hline Second operation for sHPT (\%) & $5(5.8 \%)$ \\
\hline Total resected parathyroid glands & 326 \\
\hline
\end{tabular}

Table 3. Decrease of PTH

\begin{tabular}{lll}
\hline Decrease of PTH & Patients & $\%$ \\
\hline$>50 \%$ decrease of PTH at $15 \mathrm{~min}$ & $84 / 86$ & $98 \%$ \\
\hline$>90 \%$ decrease of PTH at $15 \mathrm{~min}$ & $72 / 86$ & $84 \%$ \\
\hline No $>50 \%$ decrease of PTH & $1 / 86$ & $1 \%$ \\
\hline
\end{tabular}

in PTH greater than $50 \%$ of preoperative PTH. More than 90\% decrease in PTH values was recorded in 72 patients (84\%). The patient with supernumerary parathyroid glands showed no changes $>50 \%$ when $4 / 5$ glands were excised (Table 3).

Postoperative complications were seen in 3 patients (3.4\%). In 2 patients there was a re-intervention for hemorrhage $(2.3 \%)$, and one patient $(1.2 \%)$ had transient dysphonia which was resolved at 3 months.

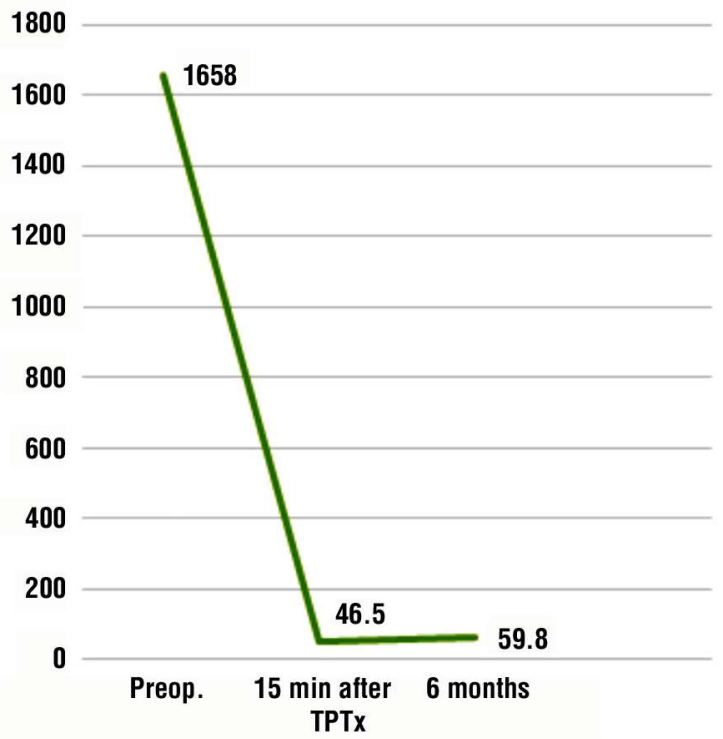

Figure 1. The mean decrease of parathyroid hormone $(\mathrm{pg} / \mathrm{mL})$ after parathyroidectomy 


\section{Discussions}

Recurrence and persistence of hyperparathyroidism after surgical treatment of sHPT is a common problem.

Excision of all parathyroid glands is performed either if we are following as a total parathyroidectomy treatment without autotransplantation or in case of autotransplantation. The existence of supernumerary parathyroids makes surgery more difficult, as is the presence of ectopic parathyroid (14).

The ideal concentration of PTH in patients with CKD is not known, but these are supported by different researchers as being between 75 and $175 \mathrm{pg} / \mathrm{ml}$ (15).

Intraoperative dosing of PTH is not commonly used in patients with sHPT, but published results suggest that this test is extremely useful in performing parathyroid tissue excision (16).

Although the rapid iPTH determination test helps the surgeon in deciding to stop exploration, he will not change the surgical procedure as bilateral cervical exploration with evidence of the 4 parathyroid glands is mandatory. The usefulness of the test is when only 3 parathyroid glands are detected, or in the case of reinterventions in patients with recurrent hyperparathyroidism. In these patients, once the normal PTH values are reached, the appearance of complications due to the wide dissection of the thyroid lobe is reduced.

The discussions can be formulated on the basis of the reliability of the analyses in patients with chronic kidney disease, respectively with the interference of the plasma halflife of PTH by renal function $(17,18)$.

There have been publications in which it has been shown that the Elecsys test does not cross react with fragment 1-38 PTH (19), but partially reacts with fragment 7-84 (20). A study of 18 patients with sHPT demonstrated that intraoperative measurement of PTH in patients with chronic kidney disease is more accurate when the test is specific for 1-84 PTH and does not interfere with fragment 7-84 (21).

IPTH value is influenced by the intraoperative manipulation of the parathyroid glands, the individual variability of PTH halflife and the physiological state of the patient.

In our study of a total of 81 patients undergoing surgery, four parathyroid glands were excised in 76 patients (94\%), 5 glands in 1 patient $(1 \%)$, three glands in 4 patients $(5 \%)$. Of the 5 patients with recurrent hyperparathyroidism, one hyperplastic parathyroid was excised.

The approach of the surgical treatment in the secondary hyperparathyroidism of renal cause remains controversial. Although there are many randomised studies, of great interest in subtotal parathyroidectomy compared to total parathyroidectomy with autotransplantation $(22,23)$, total parathyroidectomy without autotransplantation remains topical $(24,25,26)$. The advantage of total parathyroidectomy without autotransplantation is the rapid normalisation of alkaline phosphatase and serum calcium (22).

In our study the PTH had an average of $87 \%$ decrease (41\% -98\%). 84 patients (98\%) had a decrease in PTH greater than $50 \%$ of preoperative PTH. More than 90\% decrease in PTH values was recorded in 72 patients (84\%).

\section{Conclusions}

Intraoperative monitoring of PTH can confirm the complete excision of hyperfunctional parathyroid tissue, as the plasma half-life of PTH is about 5 minutes.

The intraoperative dosing of PTH in patients with sHPT represents an advantage in confirming the resection of hyperplastic parathyroid tissue and in highlighting the supernumerary or ectopic parathyroid glands.

In the case of persistent or recurrent hyperparathyroidism, the advantage of intraoperative PTH is the possibility of collecting an additional venous sample (27).

Although the predictive value of iPTH is good, we do not want routine use in sHPT surgery, but in complicated and selected cases it is a useful tool.

\section{Conflict of Interest}

The authors declare no conflicts of interests. 


\section{References}

1. Chow KM, Szeto CC, Kum LC, Kwan BC, Fung TM, Wong TY, et al. Improved health-related quality of life and left ventricular hypertrophy among dialysis patients treated with parathyroidectomy. J Nephrol. 2003;16(6):878-85.

2. Bratucu MN, Garofil ND, Radu PA, Paic V, Goleanu V, Zurzu M, et al. Measurement of Quality of Life after Total Parathyroidectomy in Patients with Secondary Hyperparathyroidism and End Stage Renal Disease. Chirurgia (Bucur). 2015;110(6):511-517.

3. Nussbaum SR, Thompson AR, Hutcheson KA, Gaz RD, Wang CA. Intraoperative measurement ofparathyroid hormone in the surgical management of hyperparathyroidism. Surgery. 1988;104(6):1121-7.

4. Stratmann SL, Kuhn JA, Bell MS, Preskitt JS, O’Brien JC, Gable DR, et al. Comparison of quick parathyroid assayfor uniglandular and multiglandularparathyroid disease. Am J Surg. 2002;184(6):57881; discussion 581.

5. Vignali E1, Picone A, Materazzi G, Steffe S, Berti P, Cianferotti L, Cetani F, Ambrogini E, Miccoli P, Pinchera A, Marcocci C. A quick intraoperative parathyroid hormone assay in the surgical management of patients with primary hyperparathyroidism: a study of 206 consecutive cases. Eur J Endocrinol. 2002;146(6):783-8.

6. Trupka A, Hallfeldt K, Horn K, Gärtner R, Landgraf R. Intraoperatives monitoring des intakten Parathormons (iPTH) in der Chirurgie des primären Hyperparathyreoidismus mit einem neuen Schnelltest. Chirurg. 2001;72:578-83.

7. Miccoli P, Berti P, Conte M, Raffaeli M, Materazzi G. Minimally invasive video assisted parathyroidectomy: lessons learned from 137 cases. J Am Coll Surg. 2000;191(6):613-8.

8. Chapuis Y, Icard P, Fulla Y, Nonnenmacher L, Bonnichon P, Louvel $A$, et al. Parathyroid adenomectomy under local anesthesia with intra-operative monitoring of UcAMP and/or 1-84 PTH. World J Surg. 1992;16(4):570-5.

9. Dralle H, Lorenz K, Nguyen-Thanh P. Minimally invasive video assisted parathyroidectomy — selective approach to localized single gland adenoma. Langenbecks Arch Surg. 1999;384(6):556-62.

10. Maier GW, Kreis ME, Renn W, Pereira PL, Häring HU, Becker HD. Parathyroid hormone after adenectomy for primary hyperparathyroidism. A study of peptide hormone elimination kinetics in humans. J Clin Endocrinol Metab. 1998;83(11):3852-6.

11 Kao PC, van Heerden JA, Grant CS, Klee GG, Khosla S. Clinical performance of parathyroid hormone immunometric assays. Mayo Clin Proc. 1992;67(7):637-45.

12 Hruska KA, Korkor A, Martin K, Slatopolsky E. Peripheral metabolism of intact parathyroid hormone: role of liver and kidney and the effect of chronic renal failure. J Clin Invest. 1981;67(3):885-92.

13 Proye CA, Goropoulos A, Franz C, Carnaille B, Vix M, Quievreux JL, et al. Usefulness and limits of quick intraoperative measurements of intact (1-84) parathyroid hormone in the surgical management of hyperparathyroidism: sequential measurements in patients with multiglandular disease. Surgery. 1991;110(6):1035-42.

14 Meakins JL, Milne CA, Hollomby DJ, Goltzman D. Total para- thyroidectomy:parathyroid hormone levels and supernumerary glands in hemodialysis patients. Clin Invest Med. 1984;7(1):21-5.

15 Echenique Elizondo M, Vidaur F, Amondarain JA. Funcio'n delinjerto paratiroideo subcutaneo en el transplante subcutaneo tras paratiroidectomía en el hiperparatiroidismo renal. Rev Nefrol 2004; 24:276-278.

16 Westerdahl J, Lindblom P, Bergenfelz A. Measurement of intraoperative parathyroid hormone predicts long-term operative success. Arch Surg. 2002;137(2):186-90.

17 Lokey J, Pattou F, Mondragon-Sanchez A, Minuto M, Mullineris B, Wambergue $\mathrm{F}$, et al. Intraoperative decay profile of intact (1-84) parathyroid hormone in surgery for renal hyperparathyroidism: a consecutive series of 80 patients. Surgery. 2000;128(6):1029-34.

18 Brossard JH, Cloutier M, Roy L, Lepage R, Gascon-Barré M, D'Amour P. Accumulation of a non-(1-84) molecular from of parathyroid hormone (PTH) detected by intact PTH assay in renal failure and importance in the interpretation of PTH values. J Clin Endocrinol Metab. 1996;81(11):3923-9.

19 Roth HJ. Elecsys parathyroid hormone (PTH) not detecting the large PTH fragment hPTH (7-84)? Clin Lab. 2000;46(5-6):295-9.

20 Yamashita H, Gao P, Noguchi S, Cantor T, Uchino S, Watanabe S, et al. Role of cyclase activating parathyroid hormone (1-84 PTH) measurements during parathyroid surgery. Ann Surg. 2002;236(1):105-11.

21 Yamashita H, Gao P, Cantor T, Noguchi S, Uchino S, Watanabe S, et al. Comparison of parathyroid hormone levels from the intact and whole parathyroid hormone assays after parathyroidectomy for primary and secondary hyperparathyroidism. Surgery. 2004; 135(2):149-56.

22 Rothmund M, Wagner PK, Schark C. Subtotal parathyroidectomy versus total parathyroidectomy and autotransplantation in secondary hyperparathyroidism: a randomized trial. World J Surg. 1991;15(6):745-50.

23 Malmaeus J, Akerström G, Johansson $\mathrm{H}$, Ljunghall S, Nilsson $\mathrm{P}$, Selking 0. Parathyroid surgery in chronic renal insufficiency: subtotal parathyroidectomy versus total parathyroidectomy with autotransplantation to the forearm. Acta Chir Scand. 1982; 148(3):229-38.

24 Nicholson ML, Veitch PS, Feehally J. Parathyroidectomy in chronic renal failure: comparison of three operative strategies. J. R. Coll.Surg. Edinb. 1996;41:382-387

25 Hampl H, Steinmüller T, Fröhling P, Naoum C, Leder K, Stabell U, et al. Long-term results of total parathyroidectomy without autotransplantation in patients with and without chronic renal failure. Miner Electrolyte Metab. 1999;25(3):161-70.

26 Ockert S, Willeke F, Richter A, Jonescheit J, Schnuelle P, Van Der Woude $F$, et al. Total parathyroidectomy without autotransplantation as a standard procedure in the treatment of secondary hyperparathyroidism. Langenbecks Arch Surg. 2002;387(5-6):204-9

27 Irvin GL 3rd, Molinari AS, Figueroa C, Carneiro DM. Improved success rate in reoperative parathyroidectomy with intraoperative PTH assay. Ann Surg. 1999;229(6):874-8; discussion 878-9. 